\title{
Cannabinoid hyperemesis syndrome in the pregnant patient: clinical case and literature review
}

\author{
Julien Flament ${ }^{*}$ D, Nathan Scius and Henri Thonon
}

\begin{abstract}
Background: Cannabis use is on the rise. Several cases of cannabinoid hyperemesis syndrome, secondary to chronic cannabis intoxication, have been described worldwide, but few cases have described this entity in pregnant women.

Case presentation: We describe a 29-year-old pregnant patient that had consumed cannabis and experienced uncontrolled vomiting. The use of hot baths, the rapid improvement in symptoms, and results of complementary examinations suggested a diagnosis of cannabinoid hyperemesis syndrome. The patient could return home, and she continued her pregnancy and childbirth without peculiarities.

Conclusion: Cannabinoid hyperemesis syndrome should be considered in the differential diagnosis of vomiting in pregnancy. Consumption of cannabis must be systematically included in the anamnesis. However, it seems to be somewhat unacceptable socially or medically. Consumption must be stopped to manage symptoms.
\end{abstract}

Keywords: Cannabinoid hyperemesis syndrome, Pregnancy, Cannabis, Vomiting, Cyclical vomiting syndrome

\section{Background}

Cannabinoid hyperemesis syndrome is a recent clinical entity [1] involving nausea and vomiting in chronic cannabis users. The syndrome is also frequently associated with abdominal pain and compulsive showers or hot baths, which can attenuate the symptomatology $[1,2]$.

The diagnosis of cannabinoid hyperemesis syndrome is based on the exclusion of other causes, and the disappearance of symptoms once cannabis consumption is terminated [2]. The diagnosis and treatment of cannabinoid hyperemesis syndrome presents a challenge to the clinician. We describe a rare case of a pregnant woman that was likely to have cannabinoid syndrome. We will review the cases published to date and the current therapeutic options and discuss the peculiarity of pregnancy. Finally,

\footnotetext{
* Correspondence: julien.flament@uclouvain.be

Emergency Department, CHU UCL Namur, 1, rue Dr G. Therasse, 5530 Mont-Godinne, Yvoir, Belgium
}

we emphasize the notion that this syndrome should not be ignored, when assessing other causes of vomiting during pregnancy, such as hyperemesis gravidarum.

\section{Case presentation}

A 29-year-old patient in her first pregnancy, at 29-week and 1-day gestation, visited the emergency room for uncontrollable vomiting and epigastric pain. She reported no health problems, but she smoked tobacco and cannabis. She had consumed $2 \mathrm{~g}$ per week for 6 years. She did not have any known allergies. She reported a decline in symptoms when taking a hot bath. The cardiopulmonary clinical examination was unremarkable. Abdominal palpation showed epigastric pain without guarding or rebound. The patient had a body temperature of $35.9^{\circ} \mathrm{C}$ and displayed stable hemodynamics.

Further examinations revealed normal $\mathrm{CBC}$ but leukocytosis with WBC of 14.7 with a left shift. An abdominal ultrasound showed no detectable pathology. Obstetrically, she had a normal ultrasound, normal cardio-fetal monitoring. 


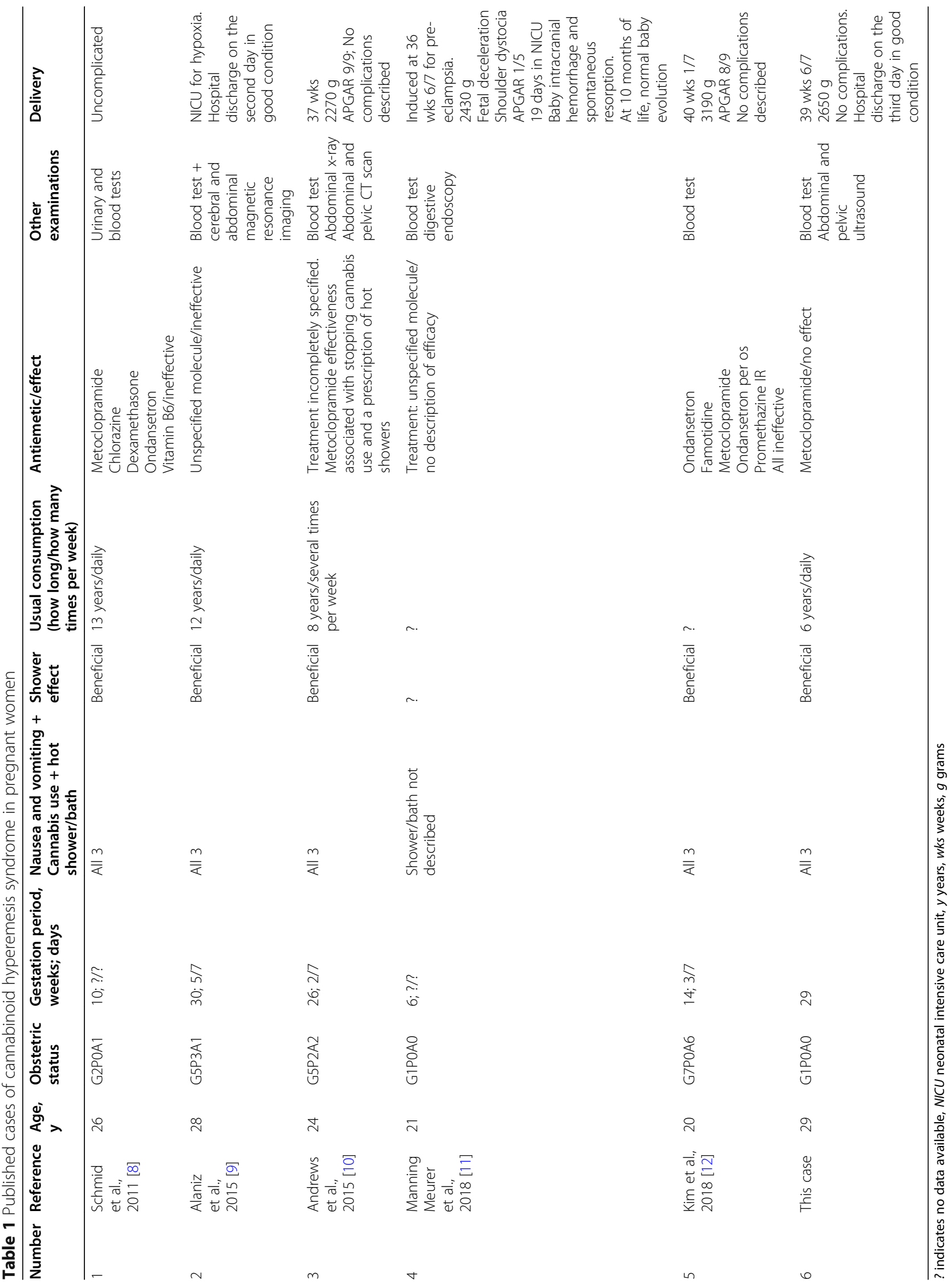


Table 2 Demographic characteristics

\begin{tabular}{ll}
\hline Characteristic & Average/median \\
\hline Age, years & $24.6 / 25$ \\
Pregnancy at diagnosis, weeks & $19.1 / 20$ \\
Time since first consumption, years & $9.75 / 10$ \\
Consumption at least several times a week, $n$ & $4 / 4$ \\
Beneficial showers/hot baths, n & $6 / 6$ \\
Need for neonatal intensive care, $n$ & $2 / 6$ \\
\hline
\end{tabular}

She was treated with acetaminophen (1000 mg), tramadol (50 mg), metoclopramide (10 mg), and butylhyoscine bromide $(10 \mathrm{mg})$. Based on the strong suspicion of cannabinoid hyperemesis syndrome and her clinical improvement in the emergency department, the details of this entity were explained to the patient, and she returned home.

The pregnancy was uncomplicated, and she gave birth at 39 weeks $6 / 7$ to a healthy 2650 -g newborn. She was discharged home with her infant uneventfully on postpartum day 3 .

\section{Discussion}

The classic clinical picture of cannabinoid hyperemesis syndrome is as follows: chronic, intensive use of cannabis, episodes of uncontrollable vomiting, and abdominal pain. A symptomatological and temporary improvement in symptoms is noted when taking a bath or hot shower. Finally, the syndrome ceases when the patient ceases cannabis use and resumes when they do not.

Cannabis use is increasing worldwide [3]. Accordingly, the number of published cases of cannabinoid hyperemesis syndrome has increased, and the pathology is of interest in various related specialties, including pediatrics [4] and forensic pathology [5]. Although the cause of the syndrome is being discussed continually and remains to be formally clarified, a few known factors are notable. First, $\Delta-9$ tetrahydrocannabinol (THC) is a CB1 receptor agonist, and it is assumed that deregulation of the receptor could cause nausea.

More than half of pregnant women experience nausea and vomiting. Hyperemesis gravidarum, which affects only 0.3 to $1 \%$ of pregnant women, is defined as persistent vomiting, more than $5 \%$ weight loss, ketonuria, and electrolyte abnormalities (particularly hypokalemia). The physiopathology remains unclear, but it is linked to hormonal activity and the production of human chorionic gonadotropin $[6,7]$.

We conducted a literature search to identify clinical cases of cannabinoid hyperemesis syndrome in pregnant patients. We employed the search terms "Cannabinoid," "Hyperemesis," and "Pregnancy" in PubMed and Google Scholar. We identified five clinical cases [8-12] and extracted their characteristics (detailed in the appendix tables) (Tables 1 and 2).
Unlike studies in non-pregnant individuals [2], the low number of studies in pregnant patients makes it difficult to perform statistical analyses. On the other hand, there are similarities between non-pregnant and pregnant individuals. Most individuals with cannabinoid hyperemesis syndrome have consumed cannabis for years, mostly daily, and the symptoms tend to improve after taking a shower or hot bath. However, cannabinoid hyperemesis syndrome is particularly complex in pregnant women. Women that use cannabis during pregnancy are more likely to experience severe nausea than those that do not [13]. Nevertheless, and paradoxically, antiemetic effects have been attributed to cannabis, in both the general population [14] and pregnant women [15]. Some authors have recommended cannabis for treating hyperemesis gravidarum [16]. One hypothesis suggested that endocannabinoids played a role in the latter pathology. However, that hypothesis was refuted in a prospective study that did not find any changes in plasma endocannabinoid levels in patients with gravidarum hyperemesis [17].

Cannabis use is increasing among pregnant women [18]. However, it seems to be somewhat unacceptable socially or medically. This stigma might lead them to hide it when taking of a comprehensive patient history. This possibility was reinforced by the absence of a link between symptomatology and cannabis use [8]. The prevalence of cannabis use in parturition is likely to be generally underestimated [19]. Some patients diagnosed with classical nausea and vomiting during pregnancy or even gravidarum hyperemesis might actually have cannabinoid hyperemesis syndrome. These entities might be differentiated clinically by the sensitivity of hyperemesis gravidarum to certain antiemetic drugs [20,21].

Potentially beneficial therapies for treating common cannabinoid hyperemesis syndrome, such as lorazepam [22] and haloperidol [23], are contraindicated in parturient women [24]. Capsaicin cream is not recommended in pregnant women. However, its usefulness could be discussed, in light of its supposed safety. Capsaicin treatment requires low dosages, and it does not cross the placental barrier [25]. Similarly, ondansetron [26] appears to have some efficacy. Although ondansetron is not recommended in the first trimester of pregnancy, its use might be permissible thereafter [24]. Metoclopramide, which can be used throughout pregnancy, has been used to treat cannabinoid hyperemesis syndrome and showed some efficacy.

This case study serves to remind physicians of the need to insist on recounting cannabis use when taking of the comprehensive patient history, particularly in parturient women with vomiting. Fortunately, the compulsive use of hot baths or showers seems specific to this clinical entity [2] and can help discriminate cannabinoid hyperemesis syndrome from other diseases.

There is a need for prospective studies that aim to determine the proportion of this syndrome among a parturient 
sample with vomiting and characterize potential differences in this subpopulation.

Randomized, controlled therapeutic trials should also be conducted to find a functional treatment for symptoms. On the one hand, an effective treatment could obviate the potential consequences of drugs of equivocal safety. On the other hand, an effective treatment is needed to avoid serious consequences of uncontrollable vomiting, which range from pneumomediastinum [27] to death [5] and acute renal insufficiency [28].

\section{Abbreviations}

CBC: Complete blood count; WBC: White blood cell

\section{Acknowledgements}

Not applicable

\section{Authors' contributions}

JF wrote the manuscript. NS corrected the manuscript. HT corrected the manuscript. The authors read and approved the final manuscript.

\section{Funding}

Not applicable

\section{Availability of data and materials}

Please contact author for data requests.

\section{Ethics approval and consent to participate}

Not applicable

\section{Consent for publication}

The patient give his content for all part of the material referenced here.

\section{Competing interests}

The authors declare that they have no competing interests.

Received: 16 June 2020 Accepted: 16 October 2020

Published online: 28 October 2020

\section{References}

1. Allen JH, de Moore GM, Heddle R, Twartz JC. Cannabinoid hyperemesis: cyclical hyperemesis in association with chronic cannabis abuse. Gut. 2004 https://doi.org/10.1136/gut.2003.036350

2. Simonetto DA, Oxentenko AS, Herman ML, Szostek JH. Cannabinoid hyperemesis: a case series of 98 patients. Mayo Clin Proc. 2012. https://doi. org/10.1016/j.mayocp.2011.10.005

3. INCB. World drug report 2014, http://www.incb.org/documents/ Publications/AnnualReports/AR2018/Annual_Report/Annual_Report_2018_F. pdf. Accessed April 1, 2020

4. Desjardins N, Stheneur C. Cannabinoid hyperemesis syndrome: a review of the literature. Arch Pediatr. https://doi.org/10.1016/j.arcped.2016.01.016.

5. Nourbakhsh M, Miller A, Gofton J, Jones G, Adeagbo B. Cannabinoid Hyperemesis Syndrome: Reports of Fatal Cases. J Forensic Sci. 2019. https:// doi.org/10.1111/1556-4029.13819.

6. Goodwin TM. Hyperemesis gravidarum. Clin Obstet Gynecol. 1998. https:// doi.org/10.1097/00003081-199809000-00014.

7. Niebyl JR. Nausea and vomiting in pregnancy. N Engl J Med. 2010. https:// doi.org/10.1056/NEJMcp1003896.

8. Schmid SM, Lapaire O, Huang DJ, Jürgens FE, Güth U. Cannabinoid hyperemesis syndrome: an underreported entity causing nausea and vomiting of pregnancy. Arch Gynecol Obstet. 2011. https://doi.org/10.1007/ s00404-010-1811-8.

9. Alaniz VI, Liss J, Metz TD, Stickrath E. Cannabinoid hyperemesis syndrome: a cause of refractory nausea and vomiting in pregnancy. Obstet Gynecol. 2015. https://doi.org/10.1097/AOG.0000000000000595.

10. Andrews KH, Bracero LA. Cannabinoid hyperemesis syndrome during pregnancy: a case report. J Reprod Med. 2015;60(9-10):430-2.
11. Manning Meurer M, Chakrala K, et al. A case of cannabinoid hyperemesis syndrome with Heliobacter pylori and preeclampsia during pregnancy. Subst Abus. 2018. https://doi.org/10.1080/08897077.2017.1356790.

12. Kim HG, Moon J, Dixon $\mathrm{H}$, et al. Recurrent nausea and vomiting in a pregnant woman with chronic marijuana use. Case Rep Obstet Gynecol. 2018. https://doi.org/10.1155/2018/9746062.

13. Roberson EK, Patrick WK, Hurwitz EL. Marijuana use and maternal experiences of severe nausea during pregnancy in Hawai'i. Hawaii J Med Public Health. 2014;73(9):283-7.

14. Carlini EA. The good and the bad effects of (-) trans-delta-9tetrahydrocannabinol (Delta 9-THC) on humans. Toxicon. 2004;44(4):461-7.

15. Westfall RE, Janssen PA, Lucas $P$, et al. Survey of medicinal cannabis use among childbearing women: patterns of its use in pregnancy and retroactive self-assessment of its efficacy against 'morning sickness'. Complement Ther Clin Pract. 2006;12(1):27-33.

16. Russo E. Cannabis treatments in obstetrics and gynecology: a historical review. J Cannabis Therapeut. https://doi.org/10.1300/J175v02v03 02.

17. Gebeh AK, Willets JM, Marczylo TH, et al. Plasma anandamide and related nacylethanolamide levels are not elevated in pregnancies complicated by hyperemesis gravidarum. J Matern Fetal Neonatal Med. 2014. https://doi. org/10.3109/14767058.2013.847413.

18. Keegan J, Parva M, Finnegan M, Gerson A, Belden M. Addiction in pregnancy. J Addict Dis. 2010. https://doi.org/10.1080/10550881003684723.

19. Jaques SC, Kingsbury A, Henshcke P, Chomchai C, Falconer J, Abdelatif ME, et al. Cannabis, the pregnant woman and her child: weeding out the myths. J Perinatol. 2014. https://doi.org/10.1038/jp.2013.180.

20. Fejzo MS, Trovik J, Grooten IJ, Sridharan K, Roseboom TJ, Vikanes A, et al. Nausea and vomiting of pregnancy and hyperemesis gravidarum. Nat Rev Dis Primers. 2019. https://doi.org/10.1038/s41572-019-0110-3

21. O'Donnell A, McParlin C, Robson SC, Beyer F, Moloney E, Bryant A, et al. Treatments for hyperemesis gravidarum and nausea and vomiting in pregnancy: a systematic review and economic assessment. Health Technol Assess. 2016. https://doi.org/10.3310/hta20740.

22. Sun S, Zimmermann AE. Cannabinoid hyperemesis syndrome. Hosp Pharm. 2013. https://doi.org/10.1310/hpj4808-650

23. Hickey JL, Witsil JC, Mycyk MB. Haloperidol for treatment of cannabinoid hyperemesis syndrome. Am J Emerg Med. 2013. https://doi.org/10.1016/j. ajem.2013.02.021.

24. Reference Center for Teratogens, https//lecrat.fr. Accessed April 1, 2020.

25. Dezieck L, Hafez Z, Conicella A, Blohm E, O'Connor MJ, Schwarz ES, et al. Resolution of cannabis hyperemesis syndrome with topical capsaicin in the emergency department: a case series. Clin Toxicol (Phila). 2017. https://doi. org/10.1080/15563650.2017.1324166.

26. Elkin K, Tai P, Winkel J, Kulkarni M, Sadler D, Truong N, et al. 337 Cannabinoid hyperemesis syndrome: 3-year practice patterns. Ann Emerg Med. 2019. https://doi.org/10.1016/j.annemergmed.2019.08.296.

27. Hernández-Ramos I, Parra-Esquivel P, López-Hernández Á, Burillo-Putze G. Spontaneuos pneumomediastinum secondary to cannabinoid hyperemesis syndrome. An Sist Sanit Navar. 2019. https://doi.org/10.23938/ASSN.0635.

28. Habboushe J, Sedor J. Cannabinoid hyperemesis acute renal failure: a common sequela of cannabinoid hyperemesis syndrome. Am J Emerg Med. 2014. https://doi.org/10.1016/j.ajem.2013.12.013.

\section{Publisher's Note}

Springer Nature remains neutral with regard to jurisdictional claims in published maps and institutional affiliations.

Ready to submit your research? Choose BMC and benefit from:

- fast, convenient online submission

- thorough peer review by experienced researchers in your field

- rapid publication on acceptance

- support for research data, including large and complex data types

- gold Open Access which fosters wider collaboration and increased citations

- maximum visibility for your research: over $100 \mathrm{M}$ website views per year

At $\mathrm{BMC}$, research is always in progress.

Learn more biomedcentral.com/submissions 